
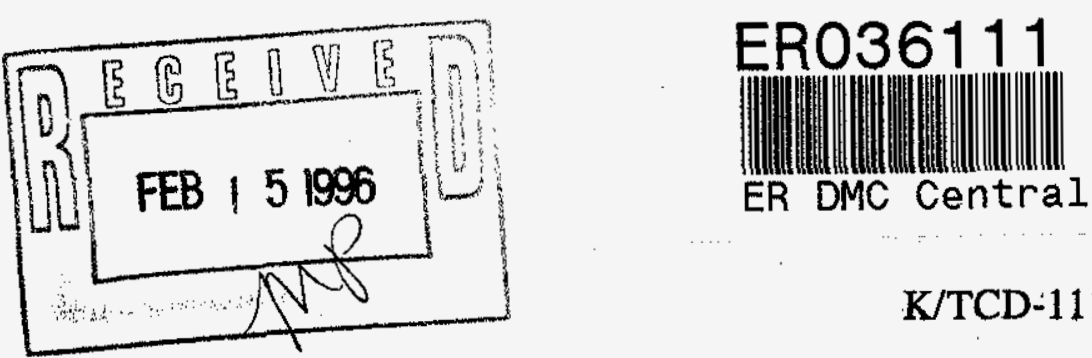

K/TCD-1116

\title{
The Stability of $\mathrm{ClO}_{2}$ as a Product of Gas Phase Decontamination Treatments
}

\author{
D. W. Simmons
}

Technical Division

September 1994

\section{CAUTION}

This document has not been given final patent clearance and js for internal use only. If this document is to be given public release, it must be cleared through the site Technical Information Office which will see that the proper patent and technical information reviews are completed in accordance with Energy Systems Policy. 
The Stability of $\mathrm{ClO}_{2}$ as a Product of Gas Phase Decontamination Treatments

D. W. Simmons

Date Published -. September 1994

Prepared by the Oak Ridge K-25 Site Oak Ridge, Tennessee 37831-7101 managed by MARTIN MARIETTA ENERGY SYSTEMS, INC. for the U.S. DEPARTMENT OF ENERGY under contract DE-AC05-84OR21400 


\section{CONTENTS}

Summary

Introduction

2

Experimental

4

Discussion

5

Conclusions

6

Acknowledgements

7

References

8 


\section{Summary}

The gas phase decontamination project is investigating the use of chlorine trifluoride $\left(\mathrm{ClF}_{3}\right)$ to fluorinate nonvolatile uranium deposits to produce uranium hexafluoride $\left(\mathrm{UF}_{6}\right)$ gas. The potential existence of chlorine dioxide $\left(\mathrm{ClO}_{2}\right)$ during gas phase decontamination with $\mathrm{ClF}_{3}$ has been the subject of recent safety discussions.

Some of the laboratory data collected during feasibility studies of the gas phase process has been evaluated for the presence of $\mathrm{ClO}_{2}$ in the product gas stream. The preliminary evidence to date can be summarized as follows.

- $\mathrm{ClO}_{2}$ was not detected in the flow loop in the absence of $\mathrm{ClF}_{3}$.

- $\mathrm{ClO}_{2}$ was not detected in the static reactors in the absence of both $\mathrm{CFF}_{3}$ and $\mathrm{ClF}$.

- $\mathrm{ClO}_{2}$ was detected in a static reactor in the absence of all fluorinating gases.

The experimental evidence suggests that $\mathrm{ClO}_{2}$ will not exist in the presence of $\mathrm{ClF}_{3}, \mathrm{ClF}$, or $\mathrm{UF}_{6}$. The data analyzed to date is insufficient to determine the stability of $\mathrm{ClO}_{2}$ in the presence of $\mathrm{ClO}_{2} \mathrm{~F}$. Thermodynamic calculations of the $\mathrm{ClF}_{3}+\mathrm{H}_{2} \mathrm{O}$ system support the experimental evidence, and suggest that $\mathrm{ClO}_{2}$ will not exist in the presence of $\mathrm{ClO}_{2} \mathrm{~F}$.

Additional experimental efforts are needed to provide a better understanding of the gas phase $\mathrm{ClF}_{3}$ treatments and the product gases. However, preliminary evidence to date suggests that $\mathrm{ClO}_{2}$ should not be present as a product during the normal operations of the gas phase decontamination project. 


\section{Introduction}

The gas phase decontamination project is investigating the use of chlorine trifluoride $\left(\mathrm{ClF}_{3}\right)$ to fluorinate nonvolatile uranium deposits to produce uranium hexafluoride $\left(\mathrm{UF}_{6}\right)$ gas. ${ }^{1}$ The long term low temperature in-situ process has been identified as a promising candidate for the recovery of uranium holdup in the gaseous diffusion process buildings. ${ }^{2}$

The laboratory effort to date has evaluated the percent recovery of uranium deposits on typical cascade materials. Quantitative results have been provided by radiological survey before and after the treatment, change in sample weight, chemical analysis, and gas stream concentrations determined over time by infrared spectroscopy. The visual appearance of the sample has been recorded for qualitative analysis.

The uranium deposits have been predominately uranyl fluoride, with reduced fluoride content ranging from less than one percent to as much as twenty percent. The reaction of $\mathrm{ClF}_{3}$ with uranyl fluoride can be related simply as

$$
2 \mathrm{ClF}_{3}+\mathrm{UO}_{2} \mathrm{~F}_{2} \rightarrow \mathrm{UF}_{6}+\mathrm{ClO}_{2} \mathrm{~F}+\mathrm{ClF}
$$

with various potential secondary reactions acknowledged, as reported by Shrewsberry and Williamson. ${ }^{3}$ The existence of the uranyl fluoride in a moist environment, allowing hydration of the deposit, complicates the chemistry additionally. Experiments during the feasibility study with wet uranyl fluoride deposited in copper seal exhaust pipe provided the approximate reaction

$$
3 \mathrm{ClF}_{3}+\mathrm{UO}_{2} \mathrm{~F}_{2} \cdot \mathrm{H}_{2} \mathrm{O} \rightarrow \mathrm{UF}_{6}+1.5 \mathrm{ClO}_{2} \mathrm{~F}+1.5 \mathrm{ClF}+2 \mathrm{HF},
$$

which appears plausible if one includes the side reaction of $\mathrm{ClF}_{3}$ with the deposit's absorbed water, the water of hydration of the deposit, and any residual water in the system. The reaction of $\mathrm{ClF}_{3}$ and water was determined by Bougon et al to be ${ }^{4}$

$$
\mathrm{ClF}_{3}+\mathrm{H}_{2} \mathrm{O} \rightarrow 0.5 \mathrm{ClO}_{2} \mathrm{~F}+0.5 \mathrm{ClF}+2 \mathrm{HF}
$$

initially, but depending on reaction conditions, secondary reactions with the products yielded a variation of products consisting of $\mathrm{ClO}_{2} \mathrm{~F}, \mathrm{ClF}, \mathrm{HF}, \mathrm{Cl}_{2}, \mathrm{O}_{2}$, and $\mathrm{ClO}_{3} \mathrm{~F}$. The authors noted that $\mathrm{ClO}_{2}$ cannot exist in the presence of $\mathrm{ClF}$ or $\mathrm{CIF}_{3}$, since fluorination would yield

$$
2 \mathrm{ClO}_{2}+\mathrm{ClF}_{3} \rightarrow 2 \mathrm{ClO}_{2} \mathrm{~F}+\mathrm{ClF}
$$

and

$$
\mathrm{ClO}_{2}+\mathrm{ClF} \rightarrow \mathrm{ClO}_{2} \mathrm{~F}+0.5 \mathrm{Cl}_{2}
$$


They also found that the reaction

$$
2 \mathrm{ClO}_{2} \mathrm{~F}+\mathrm{H}_{2} \mathrm{O} \rightarrow 2 \mathrm{HF}+2 \mathrm{ClO}_{2}+0.5 \mathrm{O}_{2}
$$

occurred on warming from $-195^{\circ} \mathrm{C}$ to room temperature, with the $\mathrm{ClO}_{2}$ susceptible to decomposition as expressed by

$$
\mathrm{ClO}_{2} \rightarrow 0.5 \mathrm{Cl}_{2}+\mathrm{O}_{2} \text {. }
$$

Cooper et al confirmed the work of Bougon, and confirmed the existence of $\mathrm{FClO}$ as a primary product of the reaction of $\mathrm{ClF}_{3}$ and $\mathrm{H}_{2} \mathrm{O}$ that disproportionates to an equilibrium mixture of mainly $\mathrm{ClO}_{2} \mathrm{~F}$ and $\mathrm{ClF}$ with a half-life of 25 seconds. $^{5}$

Shrewsberry and Williamson also evaluated the potential existence of $\mathrm{ClO}_{2}$ as a product of the reaction of $\mathrm{ClF}_{3}$ and uranyl fluoride, as reported by Ellis and Forrest, who had detected small quantities of $\mathrm{ClO}_{2}$ present at lower reaction temperatures. ${ }^{6}$ Shrewsberry prepared mixtures of $\mathrm{ClO}_{2}$ with $\mathrm{ClF}_{3}$ or $\mathrm{UF}_{6}$ and in each case the $\mathrm{ClO}_{2}$ was rapidly converted to $\mathrm{ClO}_{2} \mathrm{~F}$.

The potential existence of $\mathrm{ClO}_{2}$ during gas phase decontamination with $\mathrm{ClF}_{3}$ has been the subject of recent discussion. The experimental evidence of the potential of $\mathrm{ClO}_{2}$ as a product in the absence of $\mathrm{ClF}_{3}$ is presented. 


\section{Experimental}

The experimental systems were described in detail in reference 1 . The 4 liter flow loop consisted of a 2 in. id nickel reactor with monel, copper, and stainless steel tube and vacuum components typical to halogen chemistry research. The static reactors were simple 2 liter stainless steel vessels. The preliminary analysis of the IR spectra collected revealed that:

1. $\mathrm{ClO}_{2}$ was not detected in the flow loop in the absence of $\mathrm{CF}_{3}$ during gas-phase treatments.

Gases detected by infrared spectroscopy were $\mathrm{UF}_{6}, \mathrm{ClF}, \mathrm{ClO}_{2} \mathrm{~F}, \mathrm{HF}$, and occasional trace quantities of $\mathrm{ClO}_{3} \mathrm{~F}$ and what is believed to be $\mathrm{FClO}$. The flow loop was not allowed to remain for extended periods without $\mathrm{ClF}_{3}$, so the appearance of $\mathrm{ClO}_{2}$ in the absence of any of the other fluorinating agents was not investigated.

The gases were analyzed on-line only by infrared spectroscopy, using a $6 \mathrm{~cm}$. monel gas cell with $\mathrm{AgCl}$ windows in a Nicolet FTIR. The presence of $\mathrm{F}_{2}, \mathrm{Cl}_{2}, \mathrm{O}_{2}, \mathrm{~N}_{2}$, or any other infrared non-absorber can therefore not be confirmed or disputed experimentally.

2. $\mathrm{ClO}_{2}$ was not detected in the long term static reactors in the absence of $\mathrm{ClF}_{3}$ and $\mathrm{ClF}$.

Following consumption of the $\mathrm{ClF}_{3}$, the $\mathrm{ClF}$ was observed slowly decreasing, with a resultant increase in $\mathrm{UF}_{6}$. Gas samples have been acquired with both the $\mathrm{ClF}_{3}$ and the $\mathrm{ClF}$ consumed. IR detectable gases in the product were $\mathrm{UF}_{6}, \mathrm{ClO}_{2} \mathrm{~F}, \mathrm{HF}$, and trace $\mathrm{ClO}_{3} \mathrm{~F}$ and $\mathrm{FClO}$ on occasion.

3. $\mathrm{ClO}_{2}$ was detected in the long term static reactor in the absence of all fluorinating gases.

In an experiment conducted in the presence of $\mathrm{NaF}$ pellets, following the consumption of $\mathrm{ClF}_{3}$ and $\mathrm{ClF}$, the consumption (or dissociation) of $\mathrm{ClO}_{2} \mathrm{~F}$, and the trapping of the $\mathrm{UF}_{6}$ and most of the $\mathrm{HF}$ by the $\mathrm{NaF}$, an IR spectrum showed small quantities of $\mathrm{ClO}_{2}, \mathrm{ClO}_{3} \mathrm{~F}, \mathrm{HF}$, and $\mathrm{CO}_{2}$. A gas sample was made available for mass spectroscopy evaluation in another lab, however anomalies with this new system provided little quantitative data. Both oxygen and chlorine species were dominant in the analysis.

The static reactors did not have an on-line FTIR. The few gas samples were acquired during the brief downtime of the flow loop experiments. The gas cell was inserted in the system exhaust preceding the chemical trap, the gases expanded and allowed to equilibrate in the additional (minor) volume. There was not a method to "mix" the gases prior to sampling. The presence of moist air as a result of the sampling was monitored by acquiring several spectra over a short time and comparing to the initial spectrum. An increase in $\mathrm{HF}, \mathrm{CO}_{2}$, and $\mathrm{H}_{2} \mathrm{O}$ was indicative of additional air being ingested. If a major presence of air was suspected, the sample was redrawn. 


\section{Discussion}

The detection of minor quantities of $\mathrm{ClO}_{2}$ in the presence of $\mathrm{ClO}_{2} \mathrm{~F}$ by infrared spectroscopy is not trivial. The strongest band of $\mathrm{ClO}_{2}$, the $\nu_{3}$ fundamental is a $P-Q \cdot R$ centered at 1105 $\mathrm{cm}^{-1}(9.05 \mu)$, which is also the center of the $P-Q-R \nu_{1}$ fundamental of $\mathrm{ClO}_{2} \mathrm{~F}$. The concentration of $\mathrm{ClO}_{2} \mathrm{~F}$ is expected to be much greater than $\mathrm{ClO}_{2}$, preventing the obvious detection of the $\mathrm{ClO}_{2}$ band. Smith et al reported in GAT-T-687 that an intensity ratio of the $1273 \mathrm{~cm}^{-1}$ band to the $1105 \mathrm{~cm}^{-1}$ band of $\mathrm{ClO}_{2} \mathrm{~F}$ of less than $100: 43$ was indicative of the presence of $\mathrm{ClO}_{2}$ in $\mathrm{ClO}_{2} \mathrm{~F}^{7}$ However, Arvia and Aymonino mentioned that chlorine dioxide formation in the presence of $\mathrm{ClO}_{2} \mathrm{~F}$ was dubious, even in the absence of fluorine. ${ }^{8}$ Their published spectrum of $\mathrm{ClO}_{2} \mathrm{~F}$ gave the ratio of the two bands as 100:40.

The spectra evaluated during the gas-phase treatments has had a ratio of 100:40 - 45 for the 1273:1105 $\mathrm{cm}^{-1}$ bands of $\mathrm{ClO}_{2} \mathrm{~F}$, with the exception of the third example. $\mathrm{ClO}_{2}$ has not been detected at the $\nu_{1}$ fundamental at $945 \mathrm{~cm}^{-1}$. This peak is much weaker than the band at 1105 $\mathrm{cm}^{-1}$, and would require a much larger concentration of $\mathrm{ClO}_{2}$ present for detection.

Unfortunately, calibration spectra of $\mathrm{ClO}_{2} \mathrm{~F}$ and $\mathrm{ClO}_{2}$ were not available. The spectrum of $\mathrm{ClO}_{2} \mathrm{~F}$ has been well characterized in the past, allowing calculation of the absorbance constants. The absorbance constants for $\mathrm{ClO}_{2}$, however, are not available in this laboratory. By employing only infrared spectroscopy, particularly without calibration spectra of the suspected constituents, it is possible that small quantities of $\mathrm{ClO}_{2}$ could be present but not detected experimentally.

Preparation of $\mathrm{ClO}_{2}$ and $\mathrm{ClO}_{2} \mathrm{~F}$ in the laboratory would allow calibration spectra to be obtained of these compounds. The calibration spectra could then be used to spectrally subtract the other species from the spectra already collected, allowing a more detailed analysis of the presence of $\mathrm{ClO}_{2}$ in the product. The availability of pure samples would also provide the capability for evaluation of the stability and reactivity of $\mathrm{ClO}_{2}$ and $\mathrm{ClO}_{2} \mathrm{~F}$ as treatment gas products.

Ideally, a mass spectrometer or corrosive gas chromatograph should be employed on-line in future experiments to also allow detection of the diatomic species, such as $\mathrm{F}_{2}, \mathrm{Cl}_{2}, \mathrm{O}_{2}$, etc.. The presence (or absence) of these gases could effect the stability of the product gases, or instigate additional concerns (ie, the presence of $\mathrm{AlCl}_{3}$, more severe corrosion problems, disposal of $\mathrm{Cl}_{2}$ ). A clearer understanding of the product gases is needed to better predict the treatment success and residual gas stream resulting from gas phase $\mathrm{ClF}_{3}$ treatments in the cascade. 


\section{Conclusions}

The primary objective of the gas-phase work to date has been the demonstration of the removal of uranium compounds from gaseous diffusion substrates. All spectra collected have not been analyzed specifically for the presence of $\mathrm{ClO}_{2}$ or other minor gas phase constituents. However, the data that has been analyzed indicate that $\mathrm{ClO}_{2}$ will not exist in the presence of fluorinating agents such as $\mathrm{ClF}_{3}, \mathrm{ClF}$, or $\mathrm{UF}_{6}$. Assuming the presence of at least one of these three species at all times, $\mathrm{ClO}_{2}$ is not anticipated as a gas phase species during the normal operations of the gas phase decontamination project.

Thermodynamic calculations by Trowbridge of the $\mathrm{ClF}_{3}+\mathrm{H}_{2} \mathrm{O}$ system support the experimental evidence gathered to date, showing what species should be stable in the presence of $\mathrm{ClO}_{2}{ }^{9}$ The calculations also suggest that $\mathrm{ClO}_{2}$ would not exist in the presence of $\mathrm{ClO}_{2} \mathrm{~F}$. Experimental evidence on the stability of $\mathrm{ClO}_{2}$ in the presence of only $\mathrm{ClO}_{2} \mathrm{~F}$ has not been examined at this time.

A more comprehensive analysis of the data collected during the demonstration of the process feasibility should be conducted. The analysis could provide more definitive results or illuminate areas still needing experimental work. This would allow us to better predict not only the results of gas phase decontamination with $\mathrm{ClF}_{3}$, but also the safety of handling the product gases. If a decision is made to recycle the product gases of the $\mathrm{ClF}_{3}$ gas phase decontamination process, the need for additional knowledge of the chemistry of the chlorine - oxygen - fluorine systems will become even more important. 


\section{Acknowledgments}

The author would like to thank Dr. L. D. Trowbridge for his frequent discussions and many helpful comments regarding the chemistry of the chlorine fluorides, oxides, and oxyfluorides. The author also would like to thank Drs. D. P. Armstrong, R. D. Bundy, and L. D. Trowbridge for their prompt review and critique of this document. 


\section{References}

1. E.B. Munday and D.W. Simmons, Feasibility of Gas-Phase Decontamination of Gaseous Diffusion Equipment, K/TCD-1048, Martin Marietta Energy Systems, Oak Ridge K-25 Site, February 1993.

2. E.B. Munday, Preconceptual Design of the Gas-Phase Decontamination Demonstration Cart, K/TCD-1076, Martin Marietta Energy Systems, Oak Ridge K-25 Site, December 1993.

3. R.C. Shrewsberry and E.L. Williamson, "Chemistry of the Chlorine Trifluoride - Uranyl Fluoride Reaction", J. Inorg. Nucl. Chem. 28, 2535 - 39, (1966).

4. R. Bougon, M. Carles, and J. Aubert,"The Reaction of Chlorine Trifluoride with Water", C.R. Acad. Sc. Paris 265, 179 (1967).

5. T.D. Cooper, F.N. Dost, and C.H. Wang, "Evidence for ClOF as a Primary Product of the Reaction of $\mathrm{ClF}_{3}$ with $\mathrm{H}_{2} \mathrm{O}^{\prime \prime}$, J. Inorg. Nucl. Chem. 34, 3564 - 67, (1972).

6. J.F. Ellis and C.W. Forrest, "Some Studies in the Inorganic Chemistry of the Reaction Between Uranyl Fluoride and Chlorine Trifluoride", J. Inorg. Nucl. Chem.16, $150-153$, (1960)

7. E.A. Smith, F.C. Steinbach, and KE. Beu, "Infrared Spectra of $\mathrm{ClO}_{2} \mathrm{ClO}_{2} \mathrm{~F}$, and $\mathrm{ClO}_{3} \mathrm{~F}^{\text {", }}$ GAT-T-687, Goodyear Atomic Corp., December 1959.

8. A.J. Arvia and P.J. Aymonino, "Infra-red Absorption Spectrum of Gaseous Chloryl Fluoride $\left(\mathrm{FClO}_{2}\right)$, Spec. Acta 19, 1449 - 56, (1963).

9. L.D. Trowbridge, "ClF $+\mathrm{H}_{2} \mathrm{O}$ Thermodynamics and Kinetics", letter to R.T. Shelton, July 1993. 


\section{Distribution}

Martin Marietta Energy Systems,Inc. Oak Ridge

M. H. Albert

W. D. Altman

D. P. Armstrong

W. D. Bostick

D. H. Bunch

R. L. Fellows

M. J. Haire

J. R. Hale

L. C. Hensley

D. P. Hoffman

R. K. Kibbe

L. D. Ladd

A. F. Love

E. B. Munday

D. W. Neiswander

D. W. Simmons (3)

L. D. Trowbridge
Martin Marietta Utility Services,Inc. Oak Ridge

\section{E. J. Barber}

R. L. Ritter

Portsmouth

R. J. Riddle

A. J. Saraceno

C. A. Welch 